\title{
MEMPERTIMBANGKAN PERSPEKTIF SERVICE-DOMINANT LOGIC SEBAGAI STRATEGI PEMASARAN DI AGRO TAWON WISATA PETIK MADU LAWANG
}

\author{
Firda Melani Zalyus ${ }^{1}$, Yusri Abdillah ${ }^{2}$, Mohammad Iqbal ${ }^{3}$ \\ Universitas Brawijaya, Malang, Jawa Timur, Indonesia \\ Email: melaniza@yahoo.com ${ }^{1}$, yusriabdillah@ub.ac.id ${ }^{2}, \underline{\text { radjiq @gmail.com }}{ }^{3}$
}

\begin{abstract}
The Service-Dominant Logic (SDL) concept was first promoted by Vargo \& Lusch (2004a) because of a shift in marketing perspective that prioritizes services in the exchange process. The SDL marketing perspective consists of eight aspects namely, operant resources, resourcing, servicing and experiencing, value proposing, dialogue, value-creation networks, learning via exchanges and collaborative marketing. This study examines the extent to which the Agro Tawon Wisata Petik Madu (WPM) has implemented marketing perspectives according to the SDL concept. Data obtained through observation, interviews and documentation studies. The resource persons consisted of managers, division heads and WPM customers. Data analysis uses an interactive model (Miles, Huberman \& Saldana, 2014) which starts from Data Collection, Data Condensation, Data Display, and Conclusion Drawing. The results showed that WPM has applied all eight aspects of the marketing perspective that are in accordance with the SDL concept. WPM Managers place customers as an internal part in value creation. This can be seen from the involvement of customers from the beginning of the formation of educational tourism to the ongoing development. Managers give priority to service to customers to meet customer needs and satisfaction. However, WPM applies the service concept without knowing the SDL concept in theory. So that the benefits obtained are more optimal for the application of the service concept, it is better for WPM to carry out theoretical learning about the SDL concept.
\end{abstract}

Keywords: Service-Dominant Logic, Marketing, Services

\begin{abstract}
ABSTRAK
Konsep Service-Dominant Logic (SDL) diusung pertama kali oleh Vargo \& Lusch (2004a) karena pergeseran perspektif pemasaran yang mengutamakan layanan dalam proses pertukaran. Perspektif pemasaran SDL terdiri dari delapan aspek yaitu, sumber daya operant, resourcing, pelayanan dan pengalaman, rencana nilai, dialog, jaringan penciptaan nilai, pembelajaran melalui pertukaran dan kolaborasi pemasaran. Penelitian ini menelaah sejauh mana Agro Tawon Wisata Petik Madu (WPM) telah menerapkan persepktif pemasaran sesuai konsep SDL. Data diperoleh melalui observasi, wawancara dan studi dokumentasi. Nara sumber terdiri dari manajer, kepala divisi serta pelanggan WPM. Analisis data menggunakan model interaktif (Miles, Huberman \& Saldana, 2014) yang dimulai dari Data Collection, Data Condensation, Data Display, dan Conclusion Drawing. Hasil penelitian menunjukkan bahwa WPM telah menerapkan kedelapan aspek perspektif pemasaran yang sesuai dengan konsep SDL. Pengelola WPM menempatkan pelanggan sebagai bagian internal dalam penciptaan nilai. Hal ini dapat dilihat dari pelibatan pelanggan sejak awal dibentuknya wisata edukasi hingga pengembangan yang masih berlangsung. Pengelola mengutamakan pelayanan kepada pelanggan untuk memenuhi kebutuhan dan kepuasan pelanggan. Namun demikian WPM menerapkan konsep layanan tanpa mengetahui konsep SDL secara teori. Agar manfaat yang diperoleh lebih optimal atas penerapan konsep layanan, sebaiknya pihak WPM melakukan pembelajaran secara teori mengenai konsep SDL.
\end{abstract}

Kata kunci: Service-Dominant Logic, Pemasaran, Layanan 


\section{PENDAHULUAN}

Service-Dominant Logic adalah paradigma baru pemasaran yang mengutamakan layanan dalam proses pertukaran. ServiceDominant Logic pertama kali muncul dalam artikel berjudul Evolving to a New Dominant Logic for Marketing oleh Vargo \& Lusch (2004a). Kemunculan Service-Dominant Logic diawali karena adanya pergeseran perspektif pemasaran yang berfokus pada sumber daya tak terlihat, penciptaan nilai bersama serta relasional. Pergeseran perspektif ini berkembang dari aliran pemikiran mikroekonomika, manajemen pemasaran hingga terbentuknya fenomena jasa yang berada diluar mikroekonomika ataupun pemasaran jasa.

Vargo \& Lusch (2004a) meyakini perspektif pemasaran terpusat pada logika baru pemasaran yang menekankan keutamaan layanan dibanding barang. Salah satu premis dasar Service-Dominant Logic berbunyi "Service is the fundamental basis of exchange ". Dasar pemikiran ini manjelaskan bahwa fokus pertukaran ekonomi adalah jasa atau layanan yang dipertukarkan. Setiap pihak yang ingin mendapatkan manfaat harus memiliki kemampuan dan pengetahuan khusus dalam proses pertukaran. Sedangkan barang berfungsi sebagai mekanisasi pertukaran. Hal ini yang menggambarkan perbedaan services dalam pandangan tradisional dengan service dalam konsep Service-Dominant Logic.

Awal kemunculan pemikiran ServiceDominant Logic merupakan cara pandang baru terhadap konsep pemasaran. Paradigma baru pemasaran ini menggeser konsep GoodsDominant Logic ke arah Service-Dominant Logic. Faktor kunci Goods-Dominant Logic adalah output fisik dan transaksi diskrit. Sedangkan Service-Dominant Logic menekankan intangibility, proses pertukaran dan relasi (Tjiptono \& Chandra, 2011:448) sebagai faktor kuncinya. Perbedaan konsep ServiceDominant Logic dengan konsep pemasaran tradisional juga terletak pada posisi pelanggan. Secara umum konsep Service Dominant Logic memandang pelanggan sebagai bagian yang terintegrasi dengan perusahaan.

Dalam membangun konsep ServiceDominant Logic, Vargo \& Lusch juga memaparkan perspektif pemasaran yang bersumber dari ilmu layanan. Dalam persepktif ini pelanggan merupakan sumber daya operant dan sebagai kolaborator dalam penciptaan nilai.
Artinya model pemasaran yang diterapkan adalah dengan melibatkan pelanggan sebagai bagian internal. Lusch et.al (2008) menjelaskan pola kolaboratif dicerminkan dalam hubungan kerja yang lebih dekat, aliansi, usaha patungan, kemitraan, dan kecenderungan menuju pencarian sumber daya. Perspektif Service-Dominant Logic (Lusch et al., 2008) terdiri dari delapan aspek (lihat tabel 1.).

Tabel 1. Perubahan Perspektif dari GoodsDominant Logic ke Service-Dominant Logic

\begin{tabular}{|c|c|c|}
\hline No. & G-D Logic & S-D Logic \\
\hline 1 & $\begin{array}{c}\text { Sumber daya } \\
\text { Operand }\end{array}$ & $\begin{array}{c}\text { Sumber daya } \\
\text { Operant }\end{array}$ \\
\hline 2 & $\begin{array}{c}\text { Akuisisi sumber } \\
\text { daya }\end{array}$ & $\begin{array}{c}\text { Pencarian sumber } \\
\text { daya }\end{array}$ \\
\hline 3 & Barang dan jasa & $\begin{array}{c}\text { Layanan dan } \\
\text { pengalaman }\end{array}$ \\
\hline 4 & Harga & Rencana nilai \\
\hline 5 & Promosi & Dialog \\
\hline 6 & Rantai pasok & $\begin{array}{c}\text { Jaringan } \\
\text { penciptaan nilai }\end{array}$ \\
\hline 7 & $\begin{array}{c}\text { Memaksimalkan } \\
\text { tingkah laku }\end{array}$ & $\begin{array}{c}\text { Pembelajaran } \\
\text { melalui pertukaran }\end{array}$ \\
\hline 8 & Memasarkan kepada & $\begin{array}{c}\text { Kolaborasi } \\
\text { Pemasaran }\end{array}$ \\
\hline
\end{tabular}

Sumber: Lusch et al (2008)

Uraian di atas menuju pada kesimpulan bahwa Service-Dominant Logic sebagai paradigma baru pemasaran, menekankan penyediaan layanan/jasa sebagai tujuan utama pertukaran ekonomi dan pemasaran (Lupiyoadi, 2013:4). Barang, uang, organisasi dan jejaring merupakan perantara dari kegiatan pertukaran jasa tersebut. Prinsip yang paling fundamental dalam proses pertukaran jasa adalah pengetahuan dan keterampilan yang terspesialisasi. Kegiatan dalam Service-Dominant Logic berorientasi pada pelanggan dimana pelanggan berperan sebagai bagian dari penciptaan nilai (co-creation of value).

Permasalahan yang diangkat dalam penelitian ini difokuskan pada konsep pemasaran sesuai perspektif Service-Dominant Logic. Model pemasaran dalam konsep ini adalah kolaborasi antara perusahaan dengan pelanggan. Penelitian ini dilakukan di Agro Tawon Wisata Petik Madu yang merupakan salah satu destinasi 
wisata berbasis agro industri di Malang. Pemilihan lokasi ini didasarkan pada keunikan jenis wisatanya. Destinasi wisata agro di daerah Malang Raya pada umumnya menawarkan wisata pertanian seperti petik sayur, petik apel, petik jeruk atau pemandangan alam berupa tanaman. Sedangkan Agro Tawon Wisata Petik Madu menawarkan aktivitas berbeda dari wisata agro lainnya. Lokasi ini menyediakan edukasi cara beternak lebah serta aktivitas memanen madu lebah langsung dari sarangnya. Agro Tawon Wisata Petik Madu juga menawarkan berbagai kegiatan lain berbasis pengetahuan dan teknologi yang dikemas dalam aktivitas biotech science. Keunikan yang dimiliki Wisata Petik Madu menjadi daya tarik lebih bagi pengunjung karena berbeda dari lokasi agro wisata lainnya. Berdasarkan permasalahan yang diangkat, maka tujuan penelitian ini adalah mendeskripsikan sejauh mana Agro Tawon Wisata Petik Madu telah menerapkan konsep pemasaran yang sesuai dengan perspektif Service-Dominant Logic.

\section{KAJIAN PUSTAKA}

\section{Konsep Pemasaran}

Konsep pemasaran dimulai sejak tahun 1800-an dengan aliran pemikiran mikroekonomika, dimana pemasaran ditekankan pada pertukaran komoditas dan produk manufaktur. Pada tahun 1950-an aliran pemikiran pemasaran berkembang dalam manajemen pemasaran. Selanjutnya perkembangan pemasaran mengarah pada hubungan pemasaran, manajemen kualitas, rantai nilai dan rantai pasok serta muncul fenomena jasa yang berciri intangibiliy, heterogenity, inseparability dan perishability. Peralihan paradigma pemasaran dari goods dominant ke service dominant muncul pada awal 1990. Tabel 2. menjelaskan perkembangan teori pemasaran sejak munculnya aliran pemikiran mikroekonomika hingga munculnya perspektif Service-Dominant Logic.

Tabel 2. Perkembangan Teori Pemasaran

\begin{tabular}{|c|c|c|}
\hline $\begin{array}{c}\text { Rentang } \\
\text { Waktu }\end{array}$ & $\begin{array}{c}\text { Aliran } \\
\text { Pemikiran }\end{array}$ & Gagasan Pemasaran \\
\hline 1800 & Ekonomika & $\begin{array}{l}\text { - Distribusi dan pertukaran } \\
\text { komoditas serta produk } \\
\text { manufaktur. } \\
\text { - Institusi pemasaran } \\
\text { sebagai penyedia barang } \\
\text { dan pengatur peralihan } \\
\text { kepemilikan dari }\end{array}$ \\
\hline
\end{tabular}

\begin{tabular}{|c|c|c|}
\hline & & \begin{tabular}{lr}
\multicolumn{2}{c}{ produsen ke konsumen. } \\
- Fungsi & institusi \\
pemasaran & sebagai \\
fasilitator & pertukaran \\
barang. &
\end{tabular} \\
\hline 1950an & $\begin{array}{l}\text { Manajemen } \\
\text { Pemasaran }\end{array}$ & $\begin{array}{l}\text { - Fokus pada rancangan } \\
\text { pembuatan keputusan } \\
\text { dalam mengelola fungsi- } \\
\text { fungsi pemasaran. } \\
\text { - Awal mula muncul } \\
\text { konsep } \\
\text { pemasaran. } \\
\text { - Memuaskan pelanggan } \\
\text { sekaligus memperoleh } \\
\text { laba. }\end{array}$ \\
\hline 1980an & $\begin{array}{l}\text { Diluar } \\
\text { mikroekon } \\
\text { omika: } \\
\text { pemasaran } \\
\text { jasa }\end{array}$ & $\begin{array}{l}\text { - Relationship marketing, } \\
\text { manajemen kualitas, } \\
\text { orientasi pasar, } \\
\text { manajemen rantai nilai } \\
\text { dan rantai pasok, resource } \\
\text { management, analisis } \\
\text { jejaring. } \\
\text { - Fenomena jasa yang } \\
\text { berciri intangibiliy, } \\
\text { heterogenity, } \\
\text { inseparability } \\
\text { perishability. }\end{array}$ \\
\hline $\begin{array}{l}1990 \text { an - } \\
2000 \text { an }\end{array}$ & $\begin{array}{l}\text { Dominant } \\
\text { logic }\end{array}$ & $\begin{array}{l}\text { - Masa depan konsep } \\
\text { pemasaran terdahulu } \\
\text { dipertanyakan oleh para } \\
\text { pakar. } \\
\text { - Perumusan dan integrasi } \\
\text { dominant logic baru oleh } \\
\text { Vargo \& Lusch (2004a). } \\
\text { - Peralihan paradigma } \\
\text { pemasaran dari goods- } \\
\text { dominant view ke arah } \\
\text { service-dominant view. }\end{array}$ \\
\hline
\end{tabular}

Sumber: Tjiptono \& Chandra (2011)

\section{Strategi}

Istilah strategi pada awalnya digunakan pada saat perang yang diartikan sebagai cara atau alat yang digunakan untuk mencapai tujuan. Definisi strategi dari tahun ke tahun tidak mengalami pergeseran yang signifikan. Secara umum pengertian strategi ditekankan pada alat untuk mencapai tujuan perusahaan dalam rangka menciptakan keunggulan bersaing. Solihin (2012:64) mendefinisikan strategi sebagai cara yang dilakukan untuk mencapai tujuan serta penentuan tujuan itu sendiri. Strategi merupakan pola yang mencakup strategi yang direncanakan sejak awal serta strategi yang dipertimbangkan dan diimplementasikan kemudian oleh 
perusahaan. Rangkuti (2014:183) berpendapat bahwa strategi adalah perencanaan induk yang komprehensif, yang menjelaskan bagaimana perusahaan akan mencapai semua tujuan yang telah ditetapkan berdasarkan misi yang telah di tetapkan sebelumnya.

Hill \& Jones sebagaimana dikutip oleh Rivai \& Prawironegoro (2015:1) menyatakan "strategi adalah pola khusus atas keputusan dan tindakan yang dilakukan manajer untuk meraih tujuan organisasi". Penetapan strategi juga dilakukan berdasarkan sudut pandang pelanggan untuk mempertimbangkan kebutuhan mereka.

\section{Service-Dominant Logic}

Pengertian service secara umum/tradisional berbeda dengan makna service dalam konsep Service-Dominant Logic. Dalam Service-Dominant Logic, Vargo \& Lusch (2006a) sengaja menggunakan kata service dalam bentuk tunggal. Hal ini mengindikasikan bahwa service adalah proses, yaitu memanfaatkan operant resource (sumber daya manusia, organisasional, informasional dan relasional) yang memiliki pengetahuan dan keterampilan terspesialisasi melalui tindakan, proses dan kinerja demi manfaat dan kepentingan pihak lain atau pihak sendiri (Vargo $\&$ Lusch, 2006). Operant resource dalam konteks penelitian ini merupakan sumber daya yang diperoleh dari respon konsumen terhadap rencana nilai yang ditawarkan perusahaan. Sedangkan kata services (bentuk jamak) menyiratkan jumlah atau unit keluaran yang dilekatkan pada nilai dan jumlah keluaran yang lebih cenderung kepada Goods-Dominant Logic.

Salah satu premis dasar Service-Dominant Logic berbunyi "Service is the fundamental basis of exchange". Dasar pemikiran ini manjelaskan bahwa fokus pertukaran ekonomi adalah, jasa atau layanan yang dipertukarkan. Setiap pihak yang ingin mendapatkan manfaat harus memiliki kemampuan dan pengetahuan khusus dalam proses pertukaran. Sedangkan barang berfungsi sebagai mekanisasi pertukaran. Hal ini yang menggambarkan perbedaan services dalam pandangan tradisional dengan service dalam konsep Service-Dominant Logic.

\section{Pariwisata, Wisatawan dan Destinasi Wisata}

Pariwisata pada dasarnya adalah tentang orang yang bepergian jauh dari rumah untuk berinteraksi dengan orang lain dan tempat lain (Sharpley, 2014 dalam Lin et al, 2017). Dalam definisi ini disebutkan bahwa dalam pariwisata terjadi interaksi antara orang yang berwisata dengan penduduk serta tempat yang dikunjungi dalam rangka bepergian. Pariwisata dapat pula menyatakan bahwa seseorang tertarik pada hasil suatu kebudayaan dan tata cara hidup suatu masyarakat di tempat tujuan wisata. Kegiatan pariwisata dapat melibatkan berbagai kepentingan diantaranya kepentingan ekonomi, sosial, budaya, politik, agama, kesehatan, ataupun untuk menambah pengalaman atau belajar.

Aktivitas kepariwisataan tidak hanya menyangkut jasa atau melayani wisatawan saja. Kegiatan dalam kepariwisataan mencakup bidang produksi juga. Dalam kepariwisataan terdapat kegiatan melayani wisatawan mulai dari keberangkatannya hingga tiba di daerah tujuan (Ismayanti 2010, Marpaung 2000 dalam Arjana, 2016:15). Dalam penyelenggaraan kepariwisataan dibutuhkan banyak pihak terkait seperti biro perjalanan wisata, transportasi, hotel, toko suvenir, tempat hiburan, restoran dll (Arjana 2016).

Berdasarkan uraian tentang pariwisata, diperoleh poin utama bahwa pariwisata berhubungan dengan kegiatan bepergian seseorang untuk sementara waktu dengan berbagai tujuan dan alasan, bukan untuk bekerja atau mencari nafkah. Secara umum pariwisata bertujuan untuk melepaskan diri dari kegiatan sehari-hari. Pariwisata bahkan dapat bertujuan untuk menemukan jati diri. Oleh karenanya melalui kegiatan pariwisata seseorang dapat mengetahui siapa dirinya.

Wisatawan adalah orang yang melakukan kegiatan wisata (UU No.10 tentang kepariwisataan). Wisatawan melakukan perjalanan sementara waktu dan mengunjungi tempat tertentu untuk tujuan rekreasi, pengembangan pribadi, atau mempelajari keunikan daya tarik wisata yang dikunjungi. Wisatawan merupakan subjek dalam pelayanan pariwisata. Oleh karenanya wisatawan menjadi perhatian bagi siapa pun yang terlibat dalam kegiatan pariwisata.

Tempat tertentu yang dikunjungi dalam sebuah perjalanan dengan waktu yang signifikan (Pitana \& Diarta, 2009:126) disebut destinasi. Destinasi pariwisata memiliki batasan dalam hal area geografis serta batasan negara tujuan wisata. Wisatawan yang berkunjung ke suatu destinasi memiliki alasan atas ketertarikan kujungan mereka. 
Destinasi berhubungan dengan daya tarik wisata. Suatu destinasi akan menjadi tujuan utama wisatawan jika dirancang dan dikelola secara profesional. Daya tarik wisata dapat dibagi menjadi tiga kelompok (Sunaryo, 2013:25; Arjana, 2015:36) yaitu:

a) Daya tarik wisata alam menitikberatkan pada pemanfaatan dan pengembangan potensi sumber daya yang ada di alam dan lingkungan (Sunaryo 2013) berupa pantai, laut, danau, gunung, hutan, sungai, air terjun serta keunikan lainnya yang telah tersedia di alam.

b) Daya tarik wisata budaya berbasis pada hasil karya dan ciptaan manusia baik berupa peninggalan budaya maupun nilai budaya yang masih hidup seperti ritual atau keunikan kehidupan dalam masyarakat tertentu.

c) Daya tarik wisata minat khusus/ alternatif yang disesuaikan dengan kebutuhan dan keinginan wisatawan (Sunaryo, 2013:26).

\section{METODE PENELITIAN}

\section{Jenis dan Fokus Penelitian}

Penelitian ini dirancang dengan metode kualitatif yang memungkinkan diperolehnya ideide baru dan digunakan dalam riset eksplorasi (Zikmund \& Babin, 2011). Hasil penelitian dideskripsikan dalam kata-kata dan kalimat yang jelas. Pemahaman fenomena yang dialami oleh subjek penelitian secara holistik, dideskripsikan dalam bentuk kata-kata dalam konteks alamiah dengan memanfaatkan berbagai metode alamiah (Moleong, 2014:6). Penelitian deskriptif bertujuan agar peneliti dapat menggambarkan dengan lebih baik sifat-sifat yang diketahui keberadaannya serta relevan dengan variablevariabel yang diteliti.

Seluruh variable yang diteliti dibatasi dalam focus penelitian. Sebagaimana disebutkan Moleong (2014:93) bahwa fokus penelitian bertujuan untuk membatasi studi dan untuk memenuhi kriteria inklusi-eksklusi informasi selama di lapangan. Maka dalam penelitian ini ditetapkan fokus penelitian sesuai dengan konsep pemasaran dalam perspektif ServiceDominant Logic. Adapun perspektif ServiceDominant Logic terdiri dari delapan aspek yaitu, Operant resources, Pencarian sumber daya; Pelayanan dan pengalaman; Rencana nilai; Dialog; Jaringan penciptaan nilai; Pertukaran sebagai pembelajaran; dan Kolaborasi pemasaran.

\section{Pengumplan Data}

Data diperoleh dari hasil observasi, wawancara serta studi dokumentasi. Observasi adalah suatu proses melihat, mengamati, dan mencermati serta merekam perilaku secara sistematis untuk suatu tujuan tertentu (Cartwright \& Cartwright dalam Herdiansyah, 2011:131). Kegiatan pengamatan dilaksanakan selama Bulan Januari hingga Bulan Mei 2019. Wawancara adalah percakapan dengan maksud tertentu yang dilakukan oleh dua pihak (Moleong, 2014:186) dengan tujuan mengkonstruksi mengenai orang, kejadian, organisasi, perasaan, motivasi, tuntutan, kepedulian dan lain-lain. Jenis wawancara yang digunakan dalam penelitian ini adalah wawancara semi terstruktur, yaitu wawancara dengan pertanyaan terbuka dengan pedoman wawancara sebagai patokan alur. Studi dokumentasi adalah kegiatan pengumpulan dan pengkajian beberapa informasi dari terbitan berkala, buku-buku, dokumen, foto-foto, surat kabar, media elektronik, dan referensi statistik (Zikmund \& Babin, 2011). Dokumen yang digunakan dalam penelitian ini antara lain situs pribadi, literatur online, brosur, catatan dan laporan kunjungan wisatawan ke Agro Tawon Wisata Petik Madu serta catatan dan testimoni dari pengunjung.

\section{Analisis Data dan Validitas Temuan}

Teknik analisis data yang digunakan dalam penelitian ini adalah analisis data model interaktif (Miles, Huberman \& Saldana, 2014). Analisis data model interaktif berguna untuk menganalisis data yang diperoleh sejak awal peneliti turun ke lapangan. Analisis data sudah dimulai sejak dilakukan observasi pendahuluan, wawancara, hingga ketika perolehan kesimpulan. Aktivitas analisis data dimulai dari Data Collection dilanjutkan ke Data Condensation, Data Display, dan Conclusion Drawing/Verifications. Proses penarikan kesimpulan terjadi melalui proses analisis data yang berulang. Adapaun aktivitas dan komponen analisis dalam model interaktif ini ditunjukkan oleh Gambar 1. 


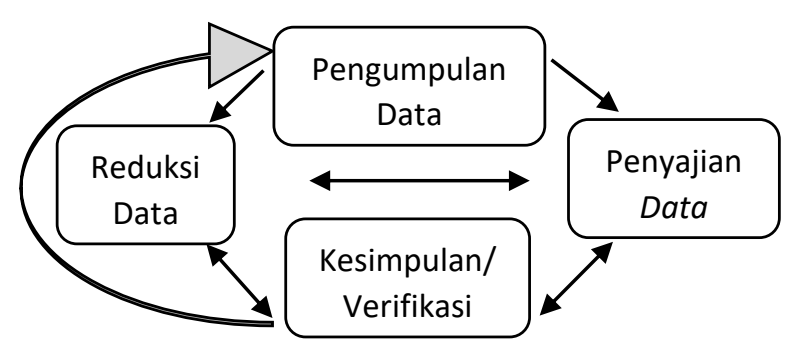

Gambar 1. Komponen Analisis Data Model Interaktif

Sumb،.: Miles, Huberman \& Saldana, 2014 (dimodifikasi)

\section{HASIL DAN PEMBAHASAN}

Pembentukan kawasan Wisata Petik Madu ini diawali dari peternakan lebah Rimba Raya pada tahun 1980. Pada masa itu kegiatan hanya difokuskan pada usaha peternakan lebah dan produksi madu lebah. Pada tahun 2001 dibentuk kawasan wisata yang melayani permintaan pelanggan terhadap edukasi perlebahan. Sejak saat itu banyak perkembangan aktivitas di kawasan wisata yang diberi nama Agro Tawon Wisata Petik Madu (WPM). WPM memiliki komitmen menjadi salah satu peternakan lebah terbesar dan terlengkap di Indonesia. Komitmen ini diwujudkan dengan meyediakan edukasi serta perlengkapan beternak lebah. Model pemasaran yang diterapkan WPM mencerminkan konsep pemasaran yang sesuai dengan perspektif Service-Dominant Logic.

WPM merupakan salah satu destinasi wisata berbasis pertanian yang difokuskan pada pembelajaran cara beternak lebah. Lokasi wisata ini terletak di jalan lintas Malang - Surabaya, tepatnya di Jl. Dr. Wahidin No. 1, Lawang. WPM dikelola oleh Bapak Hariyono sebagai manajer dan dengan satu orang supervisor dan lima kepala divisi serta beberapa karyawan. Kehadiran wisata edukasi diawali oleh adanya permintaan pengunjung untuk belajar cara beternak lebah. Bapak Hariyono menyikapi permintaan pengunjung dengan melakukan pembelajaran cara berbagi pengetahuan. Setelah memiliki pengetahuan cara mengajar, Bapak Hariyono membangun edukasi mengenai perlebahan sebagai wujud memberikan kepuasan dan pelayanan atas kebutuhan pelanggan.

Layanan merupakan landasan dasar dalam pertukaran (Vargo \& Lusch, 2008). Pernyataan ini merupakan salah satu premis dalam konsep Service-Dominant Logic. Konsep Service-
Dominant Logic hadir karena pergeseran perspektif pemasaran yang mengutamakan pelayanan melalui sumber daya tak terlihat, penciptaan nilai bersama dan relasional. Sedangkan konsep dasar layanan mengacu pada delapan perspektif. Maka dalam penerapannya delapan perspektif dalam konsep dasar layanan akan selalu berhubungan dengan perspektif pemasaran berdasarkan konsep ServiceDominant Logic. Delapan konsep dasar layanan tersebut antara lain sumber daya operant, resourcing, layanan dan pengalaman, rencana nilai, dialog, jaringan penciptaan nilai, pembelajaran melalui pertukaran dan kolaborasi pemasaran.

Produk dan layanan yang disediakan WPM cukup beragam. WPM menyediakan produk berupa madu dan olahan hasil lebah, yang terdiri dari berbagai jenis madu, royal jelly, bee pollen dan propolis. Disampnig menyediakan produk, WPM menyediakan layanan edukasi diantaranya cara beternak lebah, pertanian organik serta edukasi dalam bidang ilmu bioteknolgi. Hasil pertanian organic juga menjadi incaran pelanggan, yaitu berbagai jenis sayur dan padi organic. Layanan lain yang disediakan WPM adalah terapi sengat lebah, kegiatan outbound serta disediakannya penginapan. Berbagai produk dan layanan yang disediakan WPM dapat diterima pelanggan bergantung pada - salah satunya - strategi pemasarannya. Hasil penelitian ini membahas perspektif pemasaran yang diterapkan WPM berdasarkan konsep Service-Dominant Logic.

\section{1) Sumber Daya Operant}

Berdasarkan premis dasar konsep ServiceDominant Logic, sumber daya operant merupakan sumber dasar keunggulan bersaing (Vargo \& Lusch, 2008). Begitu pula model pemasaran yang mengutamakan sumber daya operant. Sumber daya operant berupa keahlian dan pengetahuan dapat menghasilkan nilai bagi seluruh entitas terkait dalam usaha/bisnis. Hasil penelitian ini menunjukkan WPM telah memanfaatan sumber daya operant dalam konsep pemasarannnnya.

Penerapan sumber daya operant dapat dilihat dari beberapa kebijakan manajemen WPM, diantaranya kursus Bahasa Inggris bagi karyawan, pelatihan aktivitas bahkan melakukan studi banding ke lokasi wisata lain. Pemberian kursus Bahasa Inggris pada karyawan berguna untuk meningkatkan pelayanan bagi pengunjung mancanegara serta untuk meningkatkan 
kapasitas pengelola WPM. Pelatihan bertujuan untuk menguji kesiapan karyawan serta uji coba aktivitas baru sebelum diterapkan kepada pelanggan. Studi banding dimaksudkan agar karyawan mendapat kesempatan belajar secara langsung dari tempat wisata lain yang sudah menerapkan suatu aktivitas.

\section{2) Pencarian Sumber Daya}

Proses pencarian sumber daya terdiri dari tiga aspek utama yaitu penciptaan sumber daya, integrasi sumber daya dan menghilangkan penghalang terhadap sumber daya (Lusch et al., 2008). Proses ini merupakan proses pembentukan nilai yang terjadi pada saat sumber daya potensial dapat dirubah menjadi manfaat yang spesifik. Proses penciptaan nilai harus mampu menghasilkan sumber daya lain. Penciptaan nilai selalu melibatkan pengetahuan dan kecerdasan serta keterampilan manusia. Sumber daya potensial berasal dari berbagai sumber termasuk karyawan dan pelanggan. Hasil penelitian di WPM menunjukkan penciptaan nilai dengan memanfaatkan pengetahuan dan keterampilan karyawan. Proses penciptaan nilai di lokasi wisata ini dapat dilihat melalui pemberian pelatihan bagi karyawan. Pengelola WPM selalu memberikan pelatihan, kursus bahkan studi banding ke lokasi wisata lain untuk meningkatkan pengetahuan dan keterampilan karyawannya. Hal ini bertujuan untuk memberikan layanan terbaik bagi pelanggannya.

Penciptaan sumber daya dapat pula dilakukan dengan memanfaatkan pengetahuan pelanggan. Pertanyaan, saran atau bahkan kritik dari pelanggan dapat meningkatkan pengetahuan pengelola yang artinya menambah sumber daya operant. Sebagaimana Bapak Hariyono menyebutkan beberapa ide yang berasal dari pelanggan membuat ilmu beliau meningkat dan bertambah.

Integrasi sumber daya adalah mengenai kemampuan perusahaan menggabungkan berbagai sumber daya yang ada untuk menciptakan layanan terbaik. Integrasi sumber daya dapat terjadi antara pengetahuan karyawan dengan pengalaman yang dimiliki pelanggan melalui pengorganisasian yang sesuai. Di destinasi WPM, karyawan yang sudah mumpuni dengan pengetahuan tentang perlebahan akan dihadapkan dengan pelanggan yang mempunyai pengalaman edukasi di tempat lain. Dengan adanya kondisi ini pengeloal WPM melakukan penampungan masukan dari pelanggan untuk diintegrasikan dalam bentuk aktivitas baru.

Menghilangkan penghalang merupakan aspek penentu dalam proses pencarian sumber daya. Proses ini dapat melibatkan semua pihak mulai dari karyawan hingga pelanggan bahkan budaya yang tidak sesuai dengan kondisi penciptaan sumber daya. Berdasarkan hasil wawancara diketahui bagaimana pengelola WPM melakukan proses ini. Salah satu usaha yang dilakukan adalah dengan membentuk budaya saling membantu diantara karyawan dan antar divisi. Setiap divisi harus saling mengisi kekurangan divisi lain. Kondisi ini juga bertujuan agar semua karyawan betah dan nyaman bekerja di WPM. Budaya saling membantu dapat diterapkan di WPM melalui pembentukan struktur organisasi yang jelas. Melalui struktur organisasi, setiap keluhan atau masukan dari karyawan ataupun dari pelanggan dapat ditindaklanjuti melalui prosedur yang sudah ditetapkan, sehingga tidak terjadi tumpang tindih tugas dan tanggung jawab.

\section{3) Pelayanan dan Pengalaman}

Interaksi yang terjadi antara perusahaan dengan pelanggan merupakan focus utama konsep layanan (Lusch et al., 2008) yang ditekankan pada pemberian pelayanan dan pengalaman bagi pelanggan. Menurut penuturan Bapak Hariyono, usahanya tidak mengutamakan salah satu dari produk ataupun jasa. Usaha WPM mengutamakan keduanya, karena produk dan layanan saling mendukung. Namun dalam pernyataan Bapak Hariyono tersirat adanya kebutuhan untuk saling berbagi pengatahuan dan pengalaman dengan pelanggan.

Layanan dan pemberian pengalaman bagi pelanggan WPM diwujudkan dengan menyediakan berbagai jenis madu sesuai permintaan dan kebutuhan pelanggan. Begitu pula edukasi yang disediakan di WPM merupakan hasil penyaringan permintaan pelanggan. Informasi mengenai perlebahan diberikan dalam dua jenis, yaitu edukasi gratis dan edukasi berbayar. Bagi pelanggan yang menginginkan edukasi secara sendiri-sendiri WPM akan menerapkan biaya. Sedangkan bagi pengunjung yang sudah tercukupi pengetahuan dan pengalaman secara perwakilan, edukasi ini tanpa biay. Prinsip ini diterapkan kepada seluruh pengunjung baik pengunjung rombongan maupun pengunjung perorangan.

Pemberian layanan dan pengalaman untuk mencapai kepuasan pelanggan dapat dicermati 
dari pernyataan salah seorang pelanggan yang biasa melakukan terapi sengat lebah. Setiap keluhan atau pertanyaan pelanggan akan dijawab oleh pengelola. Jika pertanyaan tidak dapat dijawab, maka akan dicarikan ahlinya untuk kemudian disampaikan kepada pelanggan. WPM juga tidak pernah menawarkan produk madu bagi kesehatan pelanggan yang melakukan terapi. Namun dengan pendekatan layanan dan pemberian pengalaman, pelanggan sendiri yang menginginkan berbagai produk tersebut.

Demikian pula pernyataan salah seorang pendamping rombongan dari Pondok Pesantren Gontor. Rombongan ini melakukan kunjungan ke WPM dalam rangka pembekalan ekonomi dan edukasi bagi siswa.

"Pelayanan yang diberikan bagus. Setahu saya edukasi disini tidak ada biaya. Informasi yang mereka berikan all out, detail dari awal sampai akhir dan dengan fasilitas yang mumpuni karena ada layarnya juga, ada pengeras suara juga. Jadi tidak sekedar menyampaikan.' (Wawancara dengan Bapak Ahmad Siddiq, S.Pd, 29 April 2019).

Pernyataan di atas cukup memberikan gambaran tentang pemahaman konsep layanan yang diterapkan WPM. Pelanggan diberi pengetahuan sesuai kebutuhan mereka. Pengalaman yang didapatkan pelanggan dapat melahirkan inovasi baru dalam pelayanan. Dalam hal ini perusahaan harus mampu mengintegrasikan pengalaman pelanggan untuk menghasilkan nilai baru. Pelanggan tidak dijadikan target promosi produk, namun WPM berusaha memberikan pengalaman dan pembelajaran yang bermanfaat sesuai kebutuhan pelanggan. Hasil wawancara dengan berbagai informan menggambarkan konsep dasar layanan pada aspek pelayanan dan pengalaman di WPM sesuai dengan perspektif Service-Dominant Logic. WPM lebih mempertimbangkan kebutuhan pelanggan dengan menyesuaikan setiap kebutuhan mereka.

\section{4) Rencana Nilai}

Menurut perspektif Service-Dominant Logic, nilai suatu produk atau jasa ditentukan oleh penerima manfaatnya, sedangkan perusahaan hanya dapat menawarkan rencana nilai (Vargo\&Lusch, 2004a). Rencana nilai dapat direalisasikan menjadi nilai ketika rencana nilai yang ditawarkan perusahaan memberikan nilai manfaat bagi pengguna. Disini pelanggan memiliki posisi yang sama dengan perusahaan. Pelanggan bukan hanya sebagai pembeli atau sebagai target penjualan, melainkan sebagai integrator dan kolaborator dalam proses penciptaan nilai.

Hasil penelitian menunjukkan adanya proses penawaran terlebih dahulu terhadap produk atau aktivitas baru. Ketika suatu produk atau aktivitas memang diminati dan dibutuhkan pelanggan, barulah WPM akan merealisasikannya. Salah satu contoh pembentukan produk WPM yang dimulai dengan membuat rencana nilai adalah bee pollen. Bee pollen merupakan produk olahan madu yang memiliki khasiat untuk mengatasi beberapa penyakit. Namun karena rasanya tidak manis seperti madu, bee pollen kurang diminati pelanggan. Pengelola WPM menjelaskan nilai manfaat bee pollen hingga menjadi produk paling dicari pelanggan. Kolaborasi dengan pelanggan tetap diteruskan meski produk bee pollen sudah sangat diminati. Penyempurnaan produk disesuaikan dengan kebutuhan dan masukan dari pelanggan.

\section{5) Dialog}

Perwujudan konsep dasar layanan sesuai dengan konsep Service-Dominant Logic diperoleh melalui penciptaan nilai bersama pelanggan. Dalam perspektif ini pelanggan adalah sebagai sumber daya operant dimana perusahaan melakukan dialog bersama pelanggan. Dialog dimaknai sebagai komunikasi dua arah. Pelanggan bukan lagi pihak yang harus disegmentasi, ditargetkan dan ditembus untuk membeli produk melalui promosi. Komunikasi dua arah dapat dibangun melalui kepercayaan, pembelajaran bersama serta saling beradaptasi. Hasil penelitian ini menunjukkan adanya dialog yang dibangun oleh pengelola WPM dengan pelanggan. Komunikasi dibangun dengan memberikan informasi mengenai berbagai aktivitas di WPM terlebih dahulu. Pengelola WPM tinggal mengikuti keinginan dan kebutuhan pengunjung, sebagaimana pernyataan Bapak Joko, kepala Divisi Sayur:

"Kita akan jelaskan terlebih dahulu edukasi apa saja yang ada disini secara umum. Dimulai dari bagian lebah, lalu lanjut ke madu, kemudian baru ke sayur. Jika mereka tertarik dengan edukasi sayur organik kita ajak belajar di kebunnya langsung. Jadi kita sampaikan informasi mengenai aktivitas yang ada disini terlebih dahulu kemudian pengunjung 
yang menentukan pilihan aktivitas apa saja yang ingin mereka lakukan." (Wawancara 18 Mei 2019).

Bentuk komunikasi yang dikembangkan oleh pengelola WPM merupakan interaksi dua arah yang melibatkan pengetahuan timbal balik. Pengelola WPM sebagai penyedia akan memberikan pengetahuan dan menerima umpan balik berupa pertanyaan atau masukan dari pelanggan. Hasil komunikasi ini akan menjadi suatu pemahaman agar terbentuk nilai yang bermanfaat bagi kedua belah pihak.

Disamping komunikasi langsung, dialog juga dapat dibangun melalui media komunikasi, seperti banner, brosur hingga penggunaan media internet. Dialog dilakukan secara massal kepada banyak pihak. Sehingga pemahaman mengenai informasi juga langsung dapat diterima oleh banyak orang. Di WPM media komunikasi yang digunakan cukup beragam. WPM memanfaatkan media sosial untuk menayangkan aktivitas mereka. Salah satu media yang digunakan yaitu instagram (IG). Menurut penuturan kepala bagian IT, Bapak Hendro, IG berfungsi sebagai sarana tanya jawab bagi pengunjung atau calon pengunjung. Melalui komunikasi dua arah akan diperoleh pemahaman mengenai kebutuhan, keinginan, harapan ataupun permasalahan dari pelanggan sebagai acuan untuk membuat keputusan dalam menjalankan usaha.

\section{6) Jaringan Penciptaan Nilai}

WPM sebagai penyedia layanan edukasi lebah dan perlengkapan beternak lebah dalam menjalankan usahanya masih menggunakan prinsp rantai pasok sambil mengembangkan jaringan penciptaan nilai. Misalnya perlengkapan beternak lebah yang sebagian besar masih disediakan dan dirakit di lokasi wisata atau perkebebunan WPM. Namun demikian pengelola WPM juga menyesuaikan dengan kebutuhan pelanggan. Ada juga peralatan yang dirakit sebagian atau setengah jadi di lokasi wisata atau di perkebunan dan sebagiannya dilanjutkan di lokasi peternakan lebah pelanggan. Begitu pula kegiatan pemberian pengetahuan cara beternak lebah yang dapat dilakukan melalui telepon. Hanya saja edukasi melalui telepon terbatas pada informasi umum, sedangkan edukasi detail belum dapat dilakukan melalui telepon.

\section{7) Pertukaran sebagai Pembelajaran}

Aplikasi pembelajaran melalui pertukaran diperankan oleh semua pihak yang terlibat dan bertujuan untuk meningkatkan kemampuan sumber daya serta kesejahteraan (Lusch et al., 2008). Penerapan proses ini dapat dilihat cara pandang pengelola WPM terhadap proses pertukaran. Fokus WPM bukan hanya pada peningkatan pembelian pelanggan, namun membuat proses pertukaran menjadi sesuatu yang berguna untuk meningkatkan pengetahuan dan pembelajaran. Penilaian penerapan pembelajaran pada WPM dapat dilihat dari hasil wawancara dengan manajer WPM berikut:

"Pertukaran ekonomi yang kita lakukan dengan pelanggan akan melahirkan inovasi dan pengembangan. Terkadang masalah-masalah yang dihadapi oleh pengunjung akan menambah ilmunya kita. Misalnya ada pertanyaanpertanyaan tertentu yang tidak bisa dijawab pada saat itu. Dari pertanyaan itu kita tergerak untuk mencari jawaban dengan cara mempelajarinya, akhirnya muncul ide-ide baru yang membuat ilmu kita berkembang, yang asalnya dari beragam pertanyaan pengunjung" (Wawancara 30 Mei 2019).

Hasil atau umpan balik pertukaran sebagai pembelajaran dapat pula tercermin pada arus kas. Ketika arus kas masuk lebih besar dibanding arus kas keluar berarti pembelajaran pengelola berhasil. Umpan balik dari sisi peningkatan arus kas atas kerjasama yang dilakukan dengan pelanggan menunjukkan kecenderungan peningkatan arus kas. Aktivitas baru cenderung meningkatkan arus kas. Jika aktivitas sudah kurang diminati maka pengelola WPM akan melakukan pembaruan aktivitas berdasarkan kebutuhan pelanggan.

\section{8) Kolaborasi Pemasaran}

Sebagaimana perspektif pemasaran berdasarkan konsep Service-Dominant Logic, pemasaran bersama dibentuk melalui kolaborasi perusahaan dengan pelanggan. Pelanggan merupakan bagian internal dalam proses pemasaran. Pelanggan bukan dipandang sebagai target atau bagian yang harus diberi tindakan untuk mendapatkan hasil bagi perusahaan. Pelanggan dirangkul dan dilibatkan dalam proses pembentukan nilai agar tercapai manfaat bagi semua pihak. Penerapan aspek kolaborasi 
pemasaran di WPM tercermin dari pernyataan Bapak Hariyono berikut:

$$
\text { “...Kita tinggal menyesuaikan }
$$

keinginan pelanggan aja. Misalnya madu ini, tidak selalu pelanggan minta yang paling bagus. Ada juga kebutuhan madu untuk industri, yang penting madunya murni, encer tidak masalah. Jadi kita layani sesuai permintaannya mereka. Jadi intinya kepuasan pelanggan jadi yang utama. Pelayanan ataupun produk terserah mereka, karena mereka yang lebih menentukan, kita kan cuma menyediakan saja." (Wawancara 30 Mei 2019).

Hasil wawancara dengan pengelola WPM menunjukkan adanya pembentukan nilai bersama pelanggan dimana pelanggan mendapat tempat untuk menyampaikan ide, saran ataupun keluhan sebagai bahan masukan dalam proses pertemuan (encounter processes). Dalam pelaksanaannya WPM selalu menyaring ide dan masukan pelanggan untuk kemudian menyediakan produk maupun layanan yang sesuai dengan kebutuhan pelanggan tersebut.

\section{KESIMPULAN DAN SARAN}

\section{Kesimpulan}

Berdasarkan hasil analisis dan pembahasan dapat ditarik kesimpulan sebagai berikut:

1. Agro Tawon Wisata Petik Madu menerapkan konsep pemasaran yang berlandaskan pelayanan untuk memenuhi kebutuhan dan kepuasan pelanggan. Sebagian besar produk dan aktivitas yang disediakan oleh WPM merupakan hasil penyaringan ide dan keluhan dari pelanggan. Pengelola dan pelanggan WPM senantiasa bekerjasama membentuk nilai yang memberikan nilai manfaat bagi kedua belah pihak.

2. Konsep pemasaran yang diterapkan WPM mengarah pada konsep pemasaran yang sesuai dengan perspektif Service-Dominant Logic. WPM mengutamakan layanan dalam proses pertukaran untuk memenuhi kepuasan pelanggan. Layanan yang diberikan kepada pelanggan mencakup pemanfaatan sumber daya operant, jaringan penciptaan nilai serta kolaborasi pemasaran yang dilakukan bersama pelanggan.
3. WPM menerapkan konsep pemasaran tersebut tanpa mengetahui konsep ServiceDominant Logic secara teori. Hal ini berarti penerapan konsep layanan bisa jadi dilandasi oleh pengetahuan di lapangan yang memungkinkan pengembangan teori lebih lanjut mengenai konsep bersangkutan.

\section{Saran}

Penelitian ini juga menghasilkan saran bagi beberapa pihak, diantaranya:

1. Bagi pengelola WPM disarankan untuk mengembangkan model pemasarannya dengan mempelajari lebih lanjut mengenai konsep pemasaran yang sesuai dengan perspektif Srvice-Dominant Logic. Pembelajaran akan meningkakan pemahaman dan menambah keahlian pengelola WPM agar pelayanan yang diberikan kepada pelanggan lebih memadai, sehingga minat kunjung pelanggan dapat ditingkatkan yang berdampak pula pada keberlanjutan usaha.

2. Bagi peneliti selanjutnya disarankan untuk dapat melakukan penelitian terkait Perspektif Service-Dominant Logic dengan menambahkan bentuk aktivitas baru di lokasi penelitiannya serta menggali lebih jauh mengenai penerapan aspek-aspek pemasaran berdasarkan konsep Service-Dominant Logic.

\section{DAFTAR PUSTAKA}

Arjana, I Gusti Bagus. 2015. Geografi Pariwisata dan Ekonomi Kreatif. Jakarta. Rajagrafindo Persada.

Herdiansyah, Haris. 2011. Metodologi Penelitian Kualitatif untuk Ilmu-Ilmu Sosial. Jakarta. Salemba Humanika.

Lupiyoadi, Rambat. 2013. Manajemen Pemasaran Jasa Berbasis Kompetensi. Jakarta. Salemba Empat.

Lusch, Robert F., Vargo, Stephen L. \& Wessel, G. 2008. Toward a conceptual foundation for service science: Contributions from service-dominant logic. IBM System Journal. 47(3): 1-10.

Miles, Matthew B., Huberman, A. Michael \& Saldana, Johnny. 2014. Qualitative Data Analysis, A Methods Sourcebook. Edisi Ketiga. USA. Sage Publication:Inc.

Moleong, Lexy J. 2014. Metodologi Penelitian Kualitatif. Edisi Revisi. Bandung. PT. Remaja Rosdakarya. 
Rangkuti, Freddy. 2014. Analisis SWOT: Teknik Membedah Kasus Bisnis. Jakarta. Gramedia Pustaka Utama.

Rivai, Abdul \& Prawironegoro, Darsono. 2015. Manajemen Strategis. Kajian Manajemen Strategis Berdasar Perubahan Lingkungan Bisnis, Ekonomi, Sosial dan Politik. Jakarta. Mitra Wacana Media.

Solihin, Ismail. 2012. Manajemen Strategik. Jakarta. Erlangga.

Sunaryo, Bambang. 2013. Kebijakan Pembangunan Destinasi Pariwisata di Indonesia. Konsep dan Aplikasinya di Indonesia. Yogyakarta. Gava Media.

Tjiptono, Fandy \& Chandra Gregorius. 2011. Service, Quality \& Satisfaction. Edisi: 3. Yogyakarta. Andi Offset.

Tjiptono, Fandy \& Chandra Gregorius. 2012. Pemasaran Strategik. Yogyakarta. Andi Offset.
Undang-Undang Republik Indonesia Nomor 10 Tahun 2009 tentang Kepariwisataan.

Vargo, Stephen R. \& Lusch, Robert F. 2004a. Evolving to a New Dominant Logic for Marketing. Journal of Marketing. 68: 117.

Zhibin Lin, Ye Chen, Raffaele Filieri. 2017. Resident-Tourist Value Co-Creation: The Role of Residents' Perceived Tourism Impacts and Life Satisfaction. Tourism Management. 61: 416-442.

Zikmund, William G. \& Babin, Barry J. 2011. Menjelajahi Riset Pemasaran. (terjemahan oleh Hirson Kurnia). Jakarta. Salemba Empat. 